\title{
Assessment of pasture and plasma minerals of cows: A case study in Pakistan
}

\author{
Zafar Iqbal Khan ${ }^{1}$, Kafeel Ahmad ${ }^{1}$, Muhammad Khalid Mukhtar ${ }^{1}$, \\ Farhad Mirzaei $^{2^{*}}$, Ghulam Hussain ${ }^{3}$ \\ ${ }^{1}$ Department of Biological Sciences, University of Sargodha, Sargodha, Pakistan \\ ${ }^{2}$ Department of Animal Production Management, Animal Science Research Institute, Karaj, Iran; \\ ${ }^{3}$ University of Engineering and Technology Lahore, Faisalabad, Pakistan \\ *Corresponding Author: farmir2001@gmail.com
}

Received 8 December 2012; revised 5 January 2013; accepted 11 January 2013

\section{ABSTRACT}

An investigation was conducted to evaluate the nutrient level of grazing livestock as influenced by the sampling periods in Punjab state district Sargodha, Pakistan. Twenty composite soil and pasture and twenty five blood samples were collected at two different sampling periods during December 2010 to March, 2011, respectively. Higher soil content of all elements except iron was observed during December than those found in Mach at the $2^{\text {nd }}$ harvest during this period but all mean values were above the critical levels investigated for soil for the requirements of forage crops. Forage, potassium, magnesium and copper levels did not differ between samplings. Calcium, sodium, zinc, manganese, cobalt and selenium were higher during December, while reverse was true for forage iron reflecting the soil iron contents. The sodium, manganese, iron and selenium in forage were found to be deficient than the requirements of livestock during both sampling times in this investigation. From the four minerals assessed in the serum calcium, magnesium and zinc levels were high after the December in March. The macro mineral which were found to be moderately deficient at this animal farm are sodium and magnesium. Micro elements most likely to limit livestock production efficiency are copper, zinc, manganese and cobalt. Specific mineral supplementation should be supplied containing copper and zinc, as both pasture and blood plasma samples exhibited their deficiency. The present investigation suggests the requirement and provision of an appropriate specificity tailored mineral mixture to ruminants in this specific studied area. The objective of this study was to determine deficiency or excess of various minerals to have the knowledge of the status of different minerl elements for supplementation if necessary.

Keywords: Soil; Forage; Serum; Ruminants Productivity; Punjab; Pakistan

\section{INTRODUCTION}

Elemental concentration of different forages is mostly affected by soil forage including $\mathrm{pH}$, fertilization practices, drainage system, plant species forage stage of maturity and, various types of interactions among different mineral elements $[1,2]$. When animals exclusively depend on forage plants to fulfill their fodder requirements, so that it is necessary to identify various attributes that may change forage composition and to measure strategy program to improve livestock productivity and performance [2]. Variable environmental limitations in the subtropical and semiarid region including drought stress during dry season, elevated temperature and intensity of light radiations result in low level of soil elemental composition. These conditions impose many restrictions on the achievement of primarily goal for the maintenance of suitable forage plant production and their quality which has been considered to support required levels of ruminant's production. The composition of the elemental concentration varies with the change of season and sites and period of sample collection, which in turn may affect elemental profile of animal consuming these forages. This situation may limit the animal production due to imbalances of mineral in the forage diet $[3,4]$. The prominent and devastating consequence of mineral deficiency are the delays puberty of heifers and late and low productivity of cows is often correlated with long calving duration [5].

Mineral composition assessment of grazing livestock in Punjab, Pakistan has received extremely small consid- 
eration and incredibly inadequate information is existing concerning mineral nutrients of accessible forage plants and mineral constituents in grazing livestock. A very little information have been available as widespread imbalances of both macro and micro minerals in different countries and Pakistan in soil, forage, and animal continuums [6-10].

The aim of the present study was to appraise the mineral composition and status of a livestock farm and evaluate the elemental composition of ruminant's blood serum, forage, and soil during two different sampling periods. This information would be useful for the livestock owners and scientists working for the improvement of livestock in different regions of Pakistan and other countries with similar ecological conditions.

\section{MATERIALS AND METHODS}

\subsection{Samples}

This investigation was conducted in the district Sargodha at a rural livestock farm in Sargodha Punjab, Pakistan. The study was done within the pasture of 25 acres located in almost subtropical/semiarid region. Samples were haphazardly chosen in the parts of the animal grazing land where animals were presently grazing. This portion of meadow has sown and superior forages and devoted for grazing at the commencement of arid season. The soil texture is loamy to clay with $\mathrm{pH}$ ranging from 7.5 to 8.4. In the investigation region, live-stock grazed round the season in the meadows mainly consisted of principally the Trifolium spp. and some plants of Brassicaceae. The main breed of cow was known as "Desi" investigated in this study. Pasture and soil samples were gathered throughout the commencement of desiccated period with knife to accumulate 20 merged pasture and soil samples. Every soil sample composed of 3-sub samples obtained from the depth of $20 \mathrm{~cm}$ as following the procedures[11]. Soil and forage samples were obtained from 25 acres pastures.

Blood samples were obtained from 25 cows in dry physiological state for both sampling periods. The age of cows lie between 3 - 5 years.

\subsection{Analytical Methods}

Samples of soil were analyzed for the determination of $\mathrm{Mn}, \mathrm{Na}, \mathrm{Zn}, \mathrm{Ca}, \mathrm{Cu}, \mathrm{Mg}, \mathrm{K}$ and $\mathrm{pH}$ following the procedures [12] and soil extractable minerals were analyzed using Flame photometer and Atomic absorption spectrophotometer [13]. The soil PH was dogged by means of 1:2 (v/v) soil: water ratio. Forage and blood samples (after separation) were subjected to wet digestion with nitric acid and per chloric acid and minerals were analyzed by the method as for soil.

\subsection{Statistical Analysis}

The data thus collected in this investigation were analyzed statistically following the SAS procedure[14]. Soil, forage and serum mineral components were analyzed to establish reference/decisive values to decide percentages of lacking samples. Average values of three replicates were taken for each determination and were subjected to statistical analysis using statistical software (Statistica, 2001) and the following model:

$$
Y_{i j}=\mu+T_{i}+e_{i j}
$$

where $Y_{i j}$ is $j^{\text {th }}$ observation in $i^{\text {th }}$ sampling time, $\mu$ is the average, $T_{i}$ is sampling time effect ( $I=1$ to 4 ) and $e_{i j}$ is the residual error. Differences were considered significant at the level of $0.05(\mathrm{p}<0.05)$.

\section{RESULTS AND DISCUSSION}

\subsection{Soil Analysis}

Mineral concentrations of soil as related to the sample collection are given in Table 1. Average soil pH was exaggerated by the sampling occasion of meadow soil. Soil $\mathrm{pH}$ standards were attributed of soil from a variety of derivation. Gough [15] did not come across momentous differences in soil $\mathrm{pH}$ with variation in time. Sampling of time reported herein was assessed after two to four month interval. The sampling period affected various levels of soil minerals are found to be higher during 1st sampling (December), While reverse was found for soil $\mathrm{Fe}$, according to critical level [12]. Soil Ca during sampling II was low which indicates probable small contents of Ca phosphates with small water solubility. Elevated percentages of calcium and copper scarce samples of soil co-related with other findings [16]. Mean soil minerals varied between sampling periods and all elements except Fe were higher in concentrations at sampling period I compared to sampling period II, while reverse was true for soil Fe. A number of factors which may perhaps have probably contributed to this tendency or climatic/edaphic [17]. As soil OM has small attraction for alkali cations, therefore, alkali invariable of the soil OM tended to the adequately short and it is probable that with the $\mathrm{OM}$ in lower amount in the soil, the concentration of Ca possibly will have elevated. Some additional factors that influence $\mathrm{Na}$ and $\mathrm{Ca}$ to a great extent may be climatic which might have affected the amount of $\mathrm{Ca}$ and Na levels of pasture land [17]. No Mg scarce samples were found according to the decisive stage of $<15 \mathrm{mg} / \mathrm{L}$ [12]. Mean soil extractable minerals varied between sampling periods and all elements except Fe were in higher concentrations at sampling period one compared to second sampling period, while reverse was true for soil Fe. A variety of factors attributed to this retort are climate and 
Table 1. Mineral concentrations of pasture soil as related to site of sample collection.

\begin{tabular}{cccccccc}
\hline \multirow{2}{*}{ Element } & C.L & \multicolumn{3}{c}{$\mathbf{1}^{\text {st }}$ sampling } & \multicolumn{3}{c}{$\mathbf{2}^{\text {nd }}$ sampling } \\
\cline { 3 - 8 } & & Mean & S.E. & \% Def & Mean & S.E. & \% Def \\
\hline $\mathbf{p H}$ & 5.5 & 7.4 & 1 & & 7.8 & - & - \\
$\mathbf{C a}$ & $<71$ & 450.4 & 15 & 4 & 278.6 & 5.4 & 0 \\
$\mathbf{M g}$ & $<30$ & 87.8 & 3.7 & 2 & 48.5 & 2.3 & 0 \\
$\mathbf{K}$ & $<62$ & 80.2 & 5.5 & 3 & 45.4 & 1.8 & 3 \\
$\mathbf{N a}$ & - & 14.35 & 1.4 & - & 9.5 & 0.8 & 2 \\
$\mathbf{Z n}$ & $<1$ & 5.78 & 0.23 & 0 & 2.63 & 0.14 & 4 \\
$\mathbf{C u}$ & $<0.3$ & 0.72 & 0.03 & 2 & 0.45 & 0.02 & 5 \\
$\mathbf{M n}$ & $<5.0$ & 80 & 4.3 & 2 & 55 & 2.3 & 0 \\
$\mathbf{F e}$ & $<2.5$ & 5.9 & 0.7 & 2 & 9.65 & 1.2 & 0 \\
\hline
\end{tabular}

Least square means (mg/kg, dry basis) are based on 20 composite samples bye sites; Means within the same row having different letters differ (p < 0.05).

soil reservoirs of these nutrients from various sources [17].

\subsection{Forage Analysis}

Concentrations of minerals in forage viz; $\mathrm{Ca}, \mathrm{Na}, \mathrm{Zn}$, $\mathrm{Mn}, \mathrm{Fe}, \mathrm{Co}$, and Se were exceedingly exaggerated by the harvesting stages (Table 2). The \% age of Ca lacking harvests were elevated for the second sampling period (55\%) compared to that at first collection period (10\%) according to the decisive value of $<0.3 \%[16,18]$. The $\%$ age of Mg lacking harvests was 40 and $60 \%$ for I and II harvesting stages, correspondingly. Small amounts of forage $\mathrm{Mg}$ can cause in deficiencies in livestock, particularly, if forage contains elevated $\mathrm{K}$ values. Vogel et al., [19] recommended in cases of hypomagnesaemia that the interface of $\mathrm{Mg}$, $\mathrm{Ca}$, and $\mathrm{K}$ is extremely significant. They recommended that a ratio of $\mathrm{K} /(\mathrm{Ca}+\mathrm{Mg})$ be used to approximate the grass tetany prospective of forage. The relative amount be supposed to be fewer than 2.2 for a forage to be secure in stipulations of its impending for inducing grass tetany in lactating cows. In this investigation, the $\mathrm{K} /(\mathrm{Ca}+\mathrm{Mg})$ relative amount did not be different between sampling stages, but all individual forage samples were higher than the 2.2 value recommended by Vogel et al., [19]. This suggests that a possible difficulty may be at hand in this cattle farm if livestock depend on forage with no supplementation. Although soil Mg tended to decrease at II sampling period, this propensity was not established in forage samples. Average forage contents of $\mathrm{Mg}$ and $\mathrm{K}$ were not exaggerated $(\mathrm{p}>0.05)$ by the sampling periods. Although soil $\mathrm{Mg}$ concentration indicated a decrease at sampling period II, this tendency was not found in forage $\mathrm{K}$ and $\mathrm{Mg}$ contents at it was higher for sampling period II. The forage Fe concentration showed this trend in forage samples. Percentage of samples deficient in Fe $100 \%$ at both sam- pling and Na 60\% - 100\% were found, whilst Se lacking samples were $72 \%$ for I and $100 \%$ at II sampling, respectively. Mean forage concentration of $\mathrm{Na}, \mathrm{Ca}, \mathrm{Zn}, \mathrm{Cu}$, Se, $\mathrm{Mn}$ and Co decreased, while \% age of $\mathrm{K}$ deficient samples was 5\% and 3\%, Na 60 and 100, Zn 10 and 50, Mn 20 and 30, Cu 30 and 50, Co 65 and 70, Se 72 and $100 \%$ for I and II sampling periods, while Fe, $\mathrm{Mg}$ and $\mathrm{K}$ concentration increased during sampling II in March ( $\mathrm{p}<$ 0.01). The increase in mineral concentrations in forages agrees with the augment of these minerals in soil at the first harvest. Deposition of heavy metals in the soil can encompass and has an influence on plant incorporation of Fe and/or Mn. Mn contents in plants depend on plant stage of development and fraction of the plant. Mn content in some plants has been reported to be extremely small throughout swift increase, and to mount up in grown-up leaves and leaf sheaths [20]. Kabata-Pendias and Pendias [21] recommended that Mn stage in forages reflects a constructive affiliation with soil organic matter and a unenthusiastic association with mounting soil $\mathrm{pH}$. The organic substance deposited in the soil of this farm might have been high in Mn, though there was a decrease in soil organic substance that may have decreased Mn accessibility to the plant. Co uptake by plants is correlated to soil concentration of Mn. Elevated level of soil Mn may be the reason of underprivileged plant uptake of Co [22]. Other circumstance that may have exaggerated Co concentrations in forages is the soil humidity at the time when samples were collected. Mn, Fe and Co lacking forage harvests for animals found in this investigation were $20 \%, 100 \%$, and $65 \%$, correspondingly, during 1st sampling and $30 \%$ and $70 \%$ during sampling period II in this investigation.

\subsection{Serum Analysis}

Mean serum minerals except Se contents were exag- 
Table 2. Forage mineral concentrations in related to sampling time.

\begin{tabular}{|c|c|c|c|c|c|c|c|}
\hline \multirow[b]{2}{*}{ Element } & \multirow[b]{2}{*}{ C. $L^{\mathrm{a}}$} & \multicolumn{3}{|c|}{$1^{\text {st }}$ sampling } & \multicolumn{3}{|c|}{$2^{\text {nd }}$ sampling } \\
\hline & & Mean $^{\text {b }}$ & S.E $E^{\mathrm{c}}$ & $\%$ Def $^{d}$ & Mean & S.E & \% Def \\
\hline Са\% & 0.3 & 0.76 & 0.02 & 10 & 0.18 & 0.01 & 55 \\
\hline Mg\% & 0.2 & 0.16 & 0.01 & 40 & 0.17 & 0.01 & 60 \\
\hline $\mathrm{K} \%$ & 0.8 & 1.19 & 0.07 & 5 & 1.29 & 0.06 & 3 \\
\hline $\mathrm{Na} \%$ & 0.08 & 0.14 & 0.02 & 60 & 0.05 & 0.02 & 100 \\
\hline $\mathrm{Zn}$ & $<30$ & 57 & 1.3 & 10 & 40 & 1.2 & 50 \\
\hline Mn & $<44$ & 55 & 2.2 & 20 & 29 & 2.5 & 30 \\
\hline $\mathrm{Fe}$ & $<50$ & 19.45 & 2.0 & 100 & 51 & 3.5 & 100 \\
\hline $\mathrm{Cu}$ & $<8$ & 14.77 & 1.4 & 30 & 11.55 & 1.6 & 50 \\
\hline Co & $<0.1$ & 0.31 & 0.02 & 65 & 0.26 & 0.02 & 70 \\
\hline Se & $<0.2$ & 0.14 & 0.01 & 72 & 0.09 & 0.002 & 100 \\
\hline
\end{tabular}

${ }^{\mathrm{a}}$ Critical level; ${ }^{\mathrm{b}}$ Least square means based on 20 forage samples; ${ }^{\mathrm{c}}$ Standard error of the least square means; ${ }^{\mathrm{d}}$ Percentage of sample below the critical level.

Table 3. Mineral concentrations of serum as related to sampling period.

\begin{tabular}{|c|c|c|c|c|c|c|c|c|}
\hline \multirow[b]{2}{*}{ Element } & \multirow[b]{2}{*}{ C.L } & \multicolumn{3}{|c|}{$1^{\text {st }}$ sampling } & \multicolumn{3}{|c|}{$2^{\text {nd }}$ sampling } & \multirow[b]{2}{*}{ Significance } \\
\hline & & Mean $^{\text {b }}$ & S.E & $\%$ Def $^{d}$ & Mean & S.E & \% Def & \\
\hline Ca mg/100ml & $<8.0$ & 7.2 & 0.06 & 11 & 8.4 & 0.05 & 2 & * \\
\hline $\mathrm{Cu} \mathrm{mg} / 100 \mathrm{ml}$ & $<50$ & 52 & 2.83 & 35 & 38 & 2.45 & 55 & $* * *$ \\
\hline Zn mg/100ml & $<60$ & 88 & 2.9 & 8 & 97 & 3.5 & 6 & $* *$ \\
\hline
\end{tabular}

${ }^{\mathrm{a}}$ Critical level; ${ }^{\mathrm{b}}$ Least square means based on 20 forage samples; ${ }^{\mathrm{c}}$ Standard error of the least square means; ${ }^{\mathrm{d}}$ percentage of sample below the critical level; ${ }^{*}$ Mean bears not common superscript are different significantly $(\mathrm{p}<0.01) ;{ }^{* *}$ Mean bears not common superscript are different significantly (p < 0.01$)$; ${ }^{* * *}$ Mean bears not common superscript are different significantly ( $\mathrm{p}<0.001)$; ns = Mean bears not common superscript are not different significantly ( $<0.05$ ).

gerated by the sampling times (Table 3). Though there were no variation in average serum Se at I and II harvesting period, the \% age of sample under the decisive level $(<4.0 \mathrm{mg} / 100 \mathrm{ml})$ vary from 20 to $15 \%$, respectively. Serum Se concentration was lesser $(p<0.05)$ at 1st than that at 2nd sampling time (4.3 and $4.5 \mu \mathrm{g} / 100$ $\mathrm{mL}$, respectively). Mean serum Ca and $\mathrm{Mg}$ were elevated $(\mathrm{p}<0.05)$ at I sampling than that at sampling period II. Nevertheless, forage $\mathrm{Ca}$ and $\mathrm{Mg}$ differ amid collection periods. This indicates a probable association between deposition of these minerals in the soil and animals consuming impure forages and/or soil which may have augmented serum $\mathrm{Mg}$ and $\mathrm{Ca}$. Ca in serum is exaggerated only by sever shortage and is intimately synchronized hormonally. Consequently, Ca in feeds would be an additional dependable criterion to asses Ca composition in cattle, higher serum $\mathrm{Mg}$ was advanced $(\mathrm{p}<0.05)$ in dry cows [23].

Mean serum Zn showed varied between animals and sampling periods. The higher concentrations of serum Zn was at sampling period II and lower at sampling period I. Mean serum Se concentrations during the I sampling (43 $\mu \mathrm{g} / 100 \mathrm{~mL}$ ) was lower ( $>0.05$ ) than during the II sampling $(4.5 \mu \mathrm{g} / 100 \mathrm{~mL})$ with $20 \%$ and $15 \%$ of the samples, respectively below the decisive level of $40 \mu \mathrm{g} / 100 \mathrm{ml}$ [24]. Mean serum Zn concentration of animals (88 vs 97 $\mu \mathrm{g} / 100)$ with $8 \%$ and $6 \%$ of the samples respectively below the critical limit suggested by McDowell et al., [24]. Mean serum copper contents showed fluctuations ( $\mathrm{p}<$ 0.05 ) between sampling intervals. Analysis of this interface recommended that serum $\mathrm{Cu}$ was elevated in lactating cows at sampling period I and lowers at sampling period II (38 $\mu \mathrm{g} / 100 \mathrm{ml}$ vs $52 \mu \mathrm{g} / 100 \mathrm{ml})$. Copper was lesser than the required level and range from 35 and 55 percent for $1^{\text {st }}$ and $2^{\text {nd }}$ sampling periods. Hypocuprosis might be aggravated by admittance molybdenum (Mo), S, $\mathrm{Fe}, \mathrm{Zn}$, and $\mathrm{Ca}$, and influence every one stages of increase and production [25]. In this investigation, Fe in forages was elevated with respect to the climatic and seasonal variation. This interface and others through Mo, $\mathrm{S}, \mathrm{Zn}$, and Ca might encompass exaggerated the levels of $\mathrm{Cu}$ found in this investigation.

\section{CONCLUSION}

The variation in season enhanced the amount of calcium, sodium, zinc and manganese along with decline the organic matter of soil. The copper, cobalt, and zinc were below the required limit for ruminant grazing 
therein thus anticipating the requirement of supplementation with specifically tailored mixture for animals to enhace the productivity of livestock at the farm.

\section{REFERENCES}

[1] McDowell, L.R., Conrad, J.H. and Ellis, G.L. (1984) Mineral deficiencies and imbalances and their diagnosis. In: Gilchrist, F.M.C. and Mackie, R.I., Eds., Symposium on Herbivore Nutrition in Subtropics and Tropics, University of Pretoria, Pretoria, 67-88.

[2] Velasquez-Pereira, J.B., McDowell, L.R., Conrad, J.H., Wilkinson, N.S. and Martin, F.G. (1997) Mineral status of soils, forages and cattle in Nicaragua. I. micro-minerals. Revista de la Facultad de Agronomía, 14, 73-89.

[3] McDowell, L.R. and Conrad, J.H. (1977) Trace mineral nutrition in Latin America. World Animal Review, 24, 2433.

[4] Songonzoni, M.G., McDowell, L.R., Wilkinson, N.S. and Harrison, J. (1996) Identification of nutritional status, emphasizing minerals in northwestern Zaire. Communications in Soil Science and Plant Analysis, 27, 2699-2712. doi:10.1080/00103629609369733

[5] McDowell, L.R. (1985) Nutrition of Grazing Ruminants in Warm Climates. Academic Press, New York, 443 p.

[6] Catalano, R., D’Argenio, B., Montanari, L., Morlotti, E. and Torelli, L. (1985) Marine geology of the northwest Sicily offshore and its relationships with mainland structures. Italian Journal of Geosciences, 104, 207-215.

[7] Khan, Z.I., Hussain, A., Ashraf, M., Ashraf, M.Y., Valeem, E.E. and Ahmad, M.S. (2004) Soil and forage (trace elements) status of a grazing pasture in the semiarid region of Pakistan. Pakistan Journal of Botany, 36, 851-856.

[8] Khan, Z.I., Ashraf, M., Hussain, A. and McDowell, L.R. (2005) Seasonal variation of trace elements in a semiarid veld pasture. Communications in Soil Science and Plant Analysis, 37, 1471-1484. doi:10.1080/00103620600585914

[9] Khan, Z.I., Hussain, A., Ashraf, M. and McDowell, L.R. (2006) Mineral status of soil and forages in south western Punjab, Pakistan. Asian-Australasian Journal of Animal Sciences, 19, 1139-1147.

[10] Khan, Z.I., Hussain, A., Ashraf, M., Ashraf, M.Y., McDowell, L.R. and Huchzermeyer, B. (2007) Copper nutrition of goats grazing native and improved pasture with seasonal variation in a semi-arid region of Pakistan. Small Ruminant Research, 67, 138-148. doi:10.1016/j.smallrumres.2005.09.030

[11] Sanchez, P.A. (1976) Properties and management of soils in the tropics. Wiley, New York.

[12] Rhue, R.D. and Kidder, D. (1983) Analytical procedures used by the IFAS extension soil testing laboratory and the interpretation of the results. University of Florida, Gainesville.

[13] Perkin Elmer Corporation (1982) Perkin elmer atomic absorption spectrophotometer: System description and maintainence. Norwalk, CT.

[14] Statistical Analysis System (1987) Statistical Analysis System. SAS Institute, Cary.

[15] Gough, I. (1979) The political economy of the welfare state. Macmillan, London.

[16] Montgomery, D.C. (1984) Design and analysis of experiments. John Wiley and Sons, Inc., New York, 538 p.

[17] Velasquez-Pereira, J., Prichard, D., McDowell, L.R., Chenoweth, P.J., Risco, C.A., Staples, C.R., Martin, F.G., Calhoun, M.C., Rojas, L.X., Williams, S.N. and Wilkinson, N.S. (1998) Long-term effects of gossypol and vitamin E in diets of dairy bulls. Journal of Dairy Science, 81, 2475-2484. doi:10.3168/jds.S0022-0302(98)70139-0

[18] NRC (1996) Nutrient tequirements of neef vattle. 7th Edition, National Academy Press, Washington DC.

[19] Vogel, R.M. and Fennessey, N.M. (1993) L-moment diagram should replace product moment diagrams. Water Resources Research, 29, 1745-1752. doi:10.1029/93WR00341

[20] Scheffer, M., Brock, W.A. and Westley, F. (2000) Mechanisms preventing optimum use of ecosystem services: An interdisciplinary theoretical analysis. Ecosystems, 3, 451471. doi:10.1007/s100210000040

[21] Kabata-Pendias, A. and Pendias, H. (1992) Trace elements in soils and plants. CRC Press Inc., Boca Raton.

[22] Norrish, K. (1975) Geochemistry and mineralogy of trace elements. In: Nicholas, D.J.D. and Egan, A.R., Eds., Trace Elements in Soil Plant-Animal Systems, Academic Press, Waltham, 55-81. doi:10.1016/B978-0-12-518150-1.50010-0

[23] Reinhardt, W., Paul, T.L., Allen, E.M., Alex, S., Yang, Y.N., Appel, M.C. and Braverman, L.E. (1988) Effect of l-thyroxine administration on the incidence of iodine induced and spontaneous lymphocytic thryoiditis in the BB/ WOR rat. Endocrin, 122, 1179-1181. doi:10.1210/endo-122-3-1179

[24] McDowell, L.R., Conrad, J.H. and Ellis, G.L. (1984) Mineral deficiencies and imbalances and their diagnosis. In: Gilchrist, F.M.C. and Mackie, R.I., Eds., Symposium on Herbivore Nutrition in Subtropics and Tropics, University of Pretoria, Pretoria, 67-88.

[25] Hansen, W.B. and Graham, J.W. (1991) Preventing alcohol, marijuana, and cigarette use among adolescents: Peer pressure resistance training vs. establishing conservative norms. Preventive Medicine, 20, 414-430. doi:10.1016/0091-7435(91)90039-7 